\title{
Late endodontic treatment of a tooth with extrusive dislocation and invasive cervical
}

\section{resorption: a clinical case report}

\section{Tratamento endodôntico tardio em dente com luxação extrusiva e reabsorção cervical invasiva:}

\author{
Relato de caso clínico
}

Tratamiento endodóntico tardío de un diente con luxación extrusiva y reabsorción cervical

invasiva: reporte de un caso clínico

Received: 08/31/2021 | Reviewed: 09/08/2021 | Accept: 09/14/2021 | Published: 09/15/2021

Ana Paula Fernandes Ribeiro

ORCID: https://orcid.org/0000-0001-5313-5003

São Paulo State University, Brazil

E-mail: apf.ribeiro@unesp.br

Julia Guerra de Andrade

ORCID: https://orcid.org/0000-0001-8167-2535

São Paulo State University, Brazil

E-mail: julia.guerra@unesp.br

Heitor César Maia

ORCID: https://orcid.org/0000-0002-4383-7287

E-mail: heitorcesarmaia@gmail.com

Caroline Loureiro

ORCID: https://orcid.org/0000-0002-9035-2960

São Paulo State University, Brazil

E-mail: caroline.loureiro@unesp.br

Gladiston Willian Lobo Rodrigues

ORCID: https://orcid.org/0000-0002-1286-3984 São Paulo State University, Brazil

E-mail: gladistonwillian@gmail.com

Rogério de Castilho Jacinto

ORCID: https://orcid.org/0000-0002-2362-8920

São Paulo State University, Brazil

E-mail: rogerio.castilho@unesp.br

\begin{abstract}
This study aims to report the clinical case of a 16 years-old male patient, who attended a private office reporting that at an accident suffered at the age of 10 years-old, which caused extrusive dislocation in both teeth 11 and 21 . At that time, the teeth were repositioned, without an adequate follow-up. Upon physical and radiographic examination, the following features were observed: presence of recurrent sinus tract on the vestibular surface, area of external cervical resorption, and a periapical lesion on tooth 21 . Endodontic treatments (necropulpectomy) were performed on teeth 11 and 21 , with the placement of a root canal dressing of calcium hydroxide and subsequent root canal filling. In addition, soft tissue flap folding was performed to treat the resorption area and to seal it with glass ionomer cement. A 7 months follow-up radiograph shows stabilization in the process of the tooth resorption and remission of the periapical lesion. In conclusion, the endodontic treatment with intracanal medication, and the sealing of the resorption area were successful to preserve the traumatized tooth. In addition, it is noteworthy that following up with the patient after the trauma episode is essential to monitor the pulp vitality of the tooth involved.
\end{abstract}

Keywords: Endodontics; Luxation, tooth; Tooth injuries; Root resorption; Tooth resorption.

\section{Resumo}

Esse estudo tem como objetivo relatar o caso clínico de um paciente do gênero masculino, 16 anos, que compareceu a um consultório particular relatando que aos 10 anos sofreu um acidente, que ocasionou luxação extrusiva nos dentes 11 e 21. Na ocasião, os dentes foram reposicionados, sem um acompanhamento adequado. Ao realizar o exame físico e radiográfico, foram observadas as seguintes características: presença de fístula recorrente na face vestibular, área de reabsorção cervical externa e lesão periapical no dente 21. Os tratamentos endodônticos (necropulpectomia) foram realizados nos dentes 11 e 21, com colocação de curativo de hidróxido de cálcio e posterior obturação endodôntica. Além disso, foi realizado o rebatimento de retalho dos tecidos moles, para realizar o tratamento da área de reabsorção e o selamento com cimento de ionômero de vidro. A radiografia de acompanhamento de 7 meses, mostra a estabilização no processo de reabsorção dentária e a remissão da lesão periapical. Em conclusão, o tratamento endodôntico com 
medicação intracanal e o selamento da área de reabsorção tiveram sucesso na preservação do dente traumatizado. Além disso, vale ressaltar que o acompanhamento do paciente após o episódio de trauma é fundamental para monitorar a vitalidade pulpar do dente envolvido.

Palavras-chave: Endodontia; Luxação dentária; Traumatismos dentários; Reabsorção da raiz; Reabsorção de dente.

\section{Resumen}

Este estudio tiene como objetivo reportar el caso clínico de un paciente de sexo masculino, de 16 años, que acudió a un consultorio privado informando que a los 10 años sufrió un accidente, que le ocasionó una luxación extrusiva en los dientes 11 y 21 reposicionados sin un adecuado seguimiento. Al examen físico y radiográfico se observaron las siguientes características: presencia de fístula recurrente en la superficie vestibular, área de reabsorción cervical externa y lesión periapical en el diente 21. Se realizaron tratamientos endodónticos (necropulpectomía) en los dientes 11 y 21 , con colocación de apósito de hidróxido de calcio y posterior relleno endodóntico. Además, se realizó el plegado del colgajo de tejidos blandos para tratar la zona de reabsorción y sellarla con cemento de ionómero de vidrio. Una radiografía de seguimiento a los 7 meses muestra estabilización en el proceso de reabsorción dental y remisión de la lesión periapical. En conclusión, el tratamiento endodóntico con medicación intracanal y el sellado de la zona de reabsorción consiguieron preservar el diente traumatizado. Además, es de destacar que el seguimiento del paciente tras el episodio traumático es fundamental para monitorizar la vitalidad pulpar del diente afectado.

Palabras clave: Endodoncia; Diente luxado; Traumatismos de los dientes; Resorción radicular; Resorción dentária.

\section{Introduction}

Due to its high prevalence, orofacial trauma is classified as a public health problem that causes physical and emotional damage to the patient (Ribeiro et al., 2021). Most traumas occur during childhood (Ramachandran et al., 2021) and adolescence, with the most affected region being the maxilla (Munoz-Sanchez et al., 2021). The maxillary central incisors are the most affected teeth in traumatic injuries, followed by the maxillary and mandibular lateral incisors (Munoz-Sanchez et al., 2021). The main factors that predispose to traumatic injuries in this region are the presence of pronounced overjet and incomplete lip seal (Lima et al., 2017).

Trauma not only affects teeth but can also cause soft tissue lacerations and injuries to support tissues. The most frequent dental injury is coronary fractures, with or without the involvement of the pulp tissue. In traumas with greater impact, teeth may undergo changes in the periodontal tissue that support them, which may lead to concussion, dislocation, or even tooth avulsion (Mordini et al., 2021).

Dental dislocation can be classified as: intrusive; lateral; or extrusive. In extrusive dislocation, there is a partial displacement of the tooth out of the socket (de Souza et al., 2020). The treatment for these cases aims to preserve dental function, neurovascular integrity and prevent infections. Thus, the dislocated tooth must be repositioned to its original position and immobilized to the adjacent teeth (Hammel \& Fischel, 2019).

Damage to the neurovascular supply can lead to changes in the function of the pulp tissue. Pulp necrosis rarely occurs in light trauma, but in moderate or severe trauma there is a greater risk of pulp necrosis and other sequelae such as root resorption and alveolar bone loss (Bratteberg et al., 2021). The development of resorption as a consequence of trauma is related to the damage suffered in the periodontium and cementum, which induces and maintains the functioning of clastic cells, and the existence of bacteria within the root canal (Finucane \& Kinirons, 2003; Patel et al., 2018). Resorption can be of two types: internal, which originates from the pulp tissue; and external, coming from the periodontal ligament (Oliveira et al., 2021; Aidos et al., 2018), and can occur in any region of the root, but usually, after trauma, it occurs in the lateral portion. Radiographically, it is characterized by the loss of tooth structure and radiolucency involving the periodontal ligament and bone (Abbott, 2016). Clinically, it can present a defect in the gingival margin, pink color in the dental crown, due to the presence of granulation tissue, and in general, it occurs asymptomatically (Gijón et al., 2016; Ahmed et al., 2014).

Even after patient care, post-traumatic complications (pulp necrosis, resorptions, root canal obliteration, and ankylosis) may appear in the short or long term. For this reason, periodic follow-up of the patient is essential, as an early diagnosis, 
associated with effective treatment, improves the prognosis, and increases the chances of preserving the tooth and its adjacent structures (de Souza et al., 2020).

This study aims to report the clinical case of a patient who suffered trauma and sought treatment after 6 years with tooth presenting pulp necrosis, sinus tract, and external coronary and cervical radicular resorption.

\section{Methodology}

Case studies use clinical files and are a good research strategy, as they report the actions taken in the management and treatment of the situations addressed (Pereira et al., 2018). The present work addresses the case study of a patient who suffered orofacial trauma and presented post-traumatic complications. In addition, to better expose and discuss the topic, a literature search was carried out in the Pubmed database, using the keywords: tooth dislocation, inflammatory resorption; pulp necrosis; trauma, root resorption, external cervical resorption, and traumatic dental injuries.

\section{Case Report}

A 16 years old systemically healthy male patient attended a private office reporting a traumatic injury suffered at the age of 10 due to a bicycle accident, which resulted in the extrusive dislocation of both central incisors (teeth 11 and 21). At that time, the teeth were repositioned, but the patient did not receive adequate guidance, and there was no periodic monitoring of the condition, with no treatment being performed. Upon physical examination of tooth 21 , on the buccal surface, a recurrent sinus tract and gingival tissue infiltration in the cervical region of the dental crown were noted (Figure 1), and slight pink coloration in the dental crown. On the palatal surface of the same tooth, a gap resulting from external cervical resorption was observed, as well as gingival tissue infiltration (Figure 2). The radiographic examination of the maxillary central incisors showed a zone of root resorption in the cervical third of teeth 11 and 21, a radiolucent area in the apex of tooth 21, and external resorption in the dental crown (Figure 3). The cold thermal test confirmed the pulp necrosis of both teeth 11 and 21.

Figure 1. Recurrent sinus tract in the region of tooth 21, infiltration of gingival tissue in the cervical region of the crown, and slight pink coloration on the distal face of the dental crown

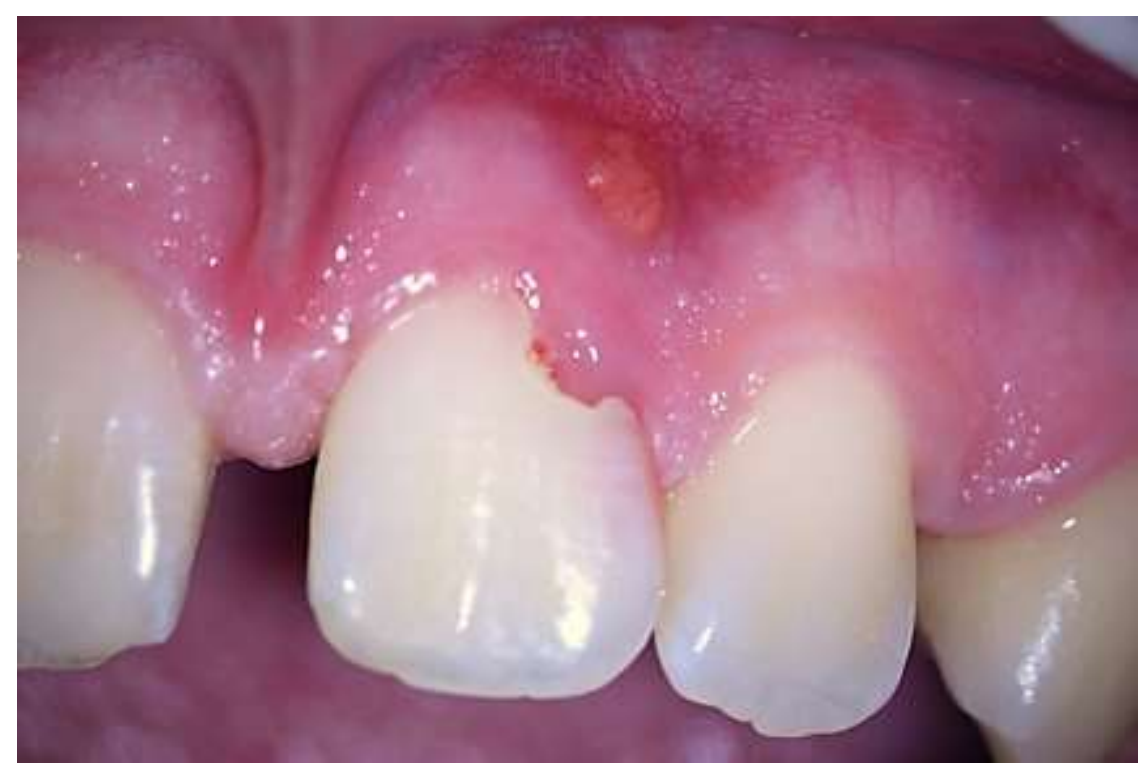

Source: Authors. 
Figure 2. Palatal view of external cervical resorption in the crown of tooth 21 , and gingival tissue infiltration in the gap region caused by resorption.

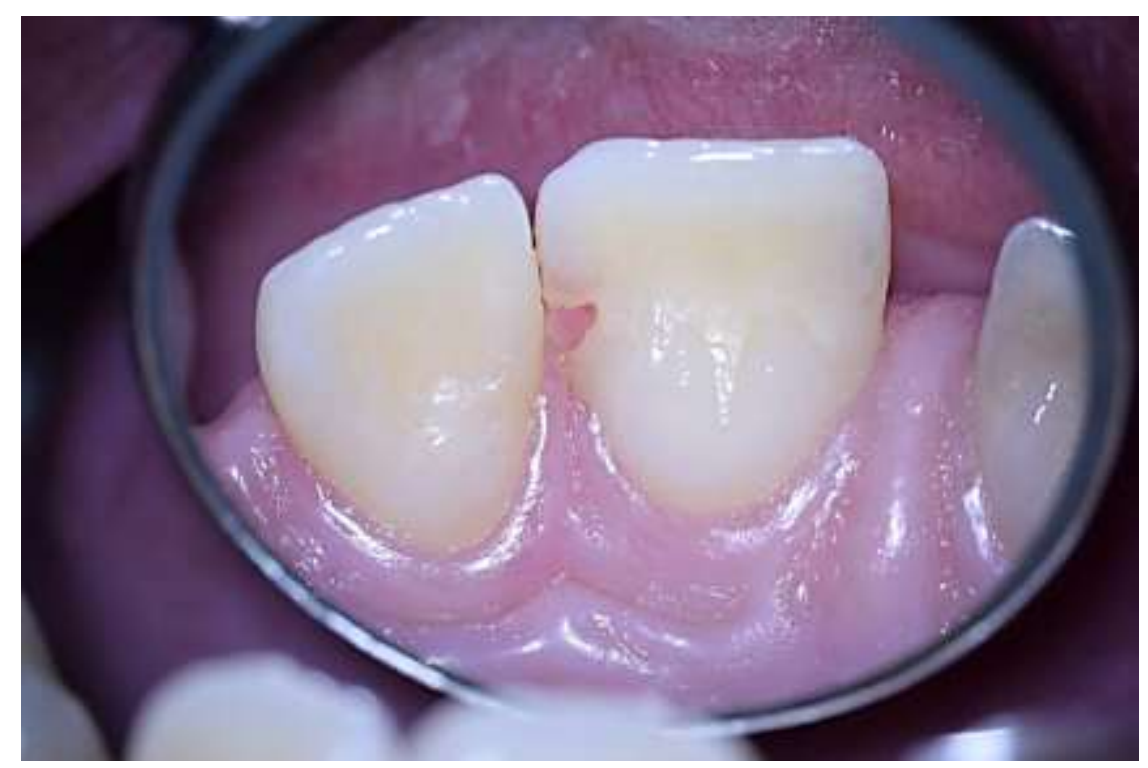

Source: Authors.

Figure 3. X-ray of teeth 11 and 21. A) An area of external root resorption is observed in the cervical third of the root of tooth 11. B) Presence of external resorption on the distal surface of the crown of dental element 21 area of external root resorption in the cervical third of the root, and a radiolucent area around the dental periapex of the same tooth, characterizing apical periodontitis.
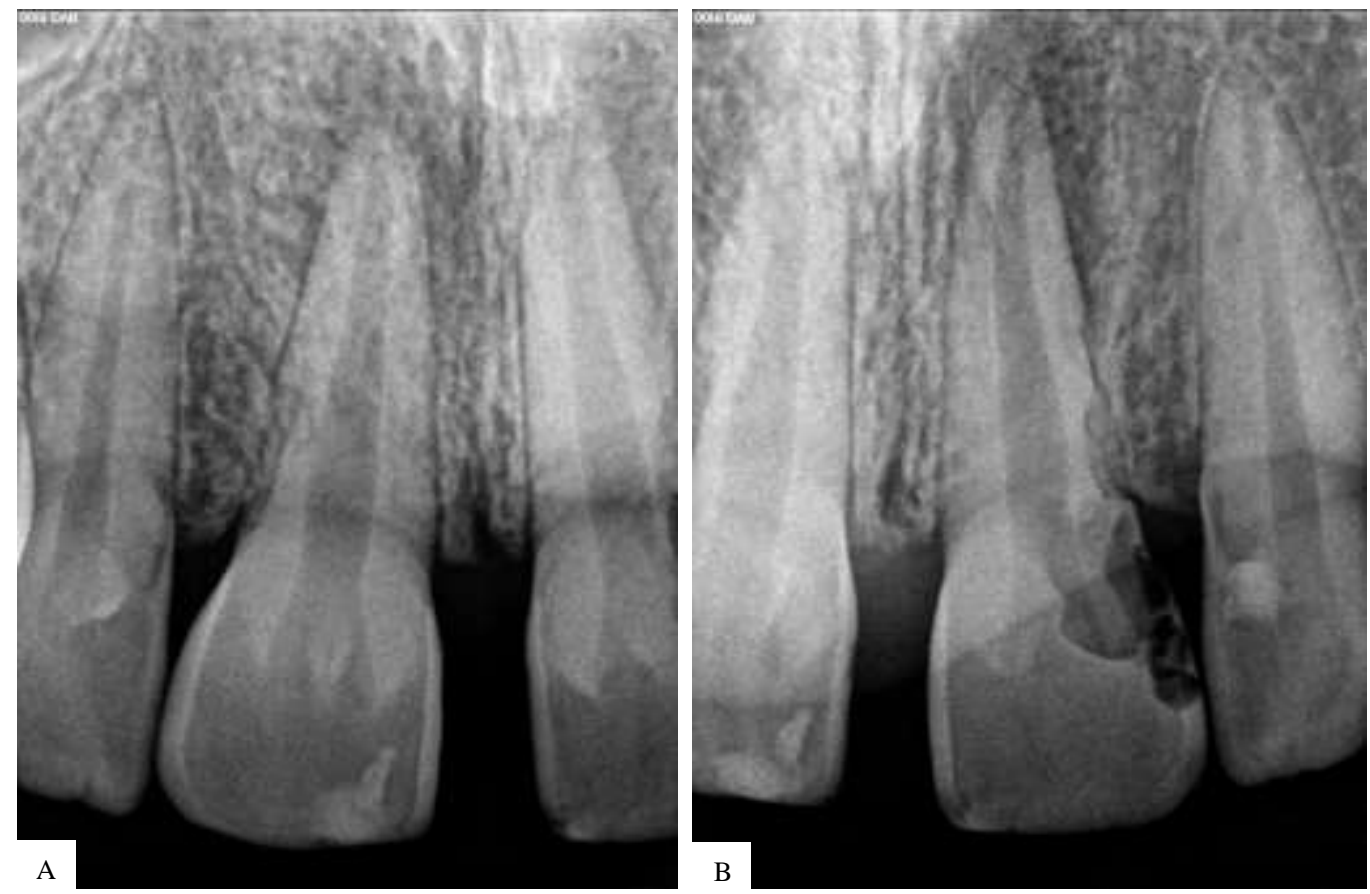

Source: Authors.

\section{Treatments}

For the treatment of external cervical resorption in the crown of tooth 21 , a soft tissue flap was performed to provide better access to the area, which was sealed with Ionoseal glass ionomer cement (Voco GmbH, Germany) (Figure 4). 
Endodontic treatments (necropulpectomy) of teeth 11 and 21 were carried out. The canals were instrumented with a rotary system - ProDesign Logic (Easy Dental Equipment, Belo Horizonte, Brazil) and irrigated with 6\% sodium hypochlorite. Intracanal medication of calcium hydroxide paste, Ultracal XS (Ultradent Products, Inc, Germany) were applied for 15 days in the root canals. Gutta-percha cone and endodontic cement Pulp Canal Sealer (Sybron Dental, Orange, CA) were used to fill the canals. At the end of the treatment, at the request of the prosthetist dentist, two-thirds of the root canal of tooth 21 was removed, for the placement of an FGM fiberglass post (@2021FGM Dental Group, Brazil) (Figure 5).

A 7-month follow-up showed a stabilization in the areas of root and coronary resorption and remission of the periapical lesion on tooth 21 (Figure 6).

Figure 4. A) Folding the soft tissue flap from teeth 21 and 22 to access and seal the external cervical resorption of tooth 21 . B) Soft tissue flap replacement and suture. C) Palatal view of the sealing of the external cervical resorption.

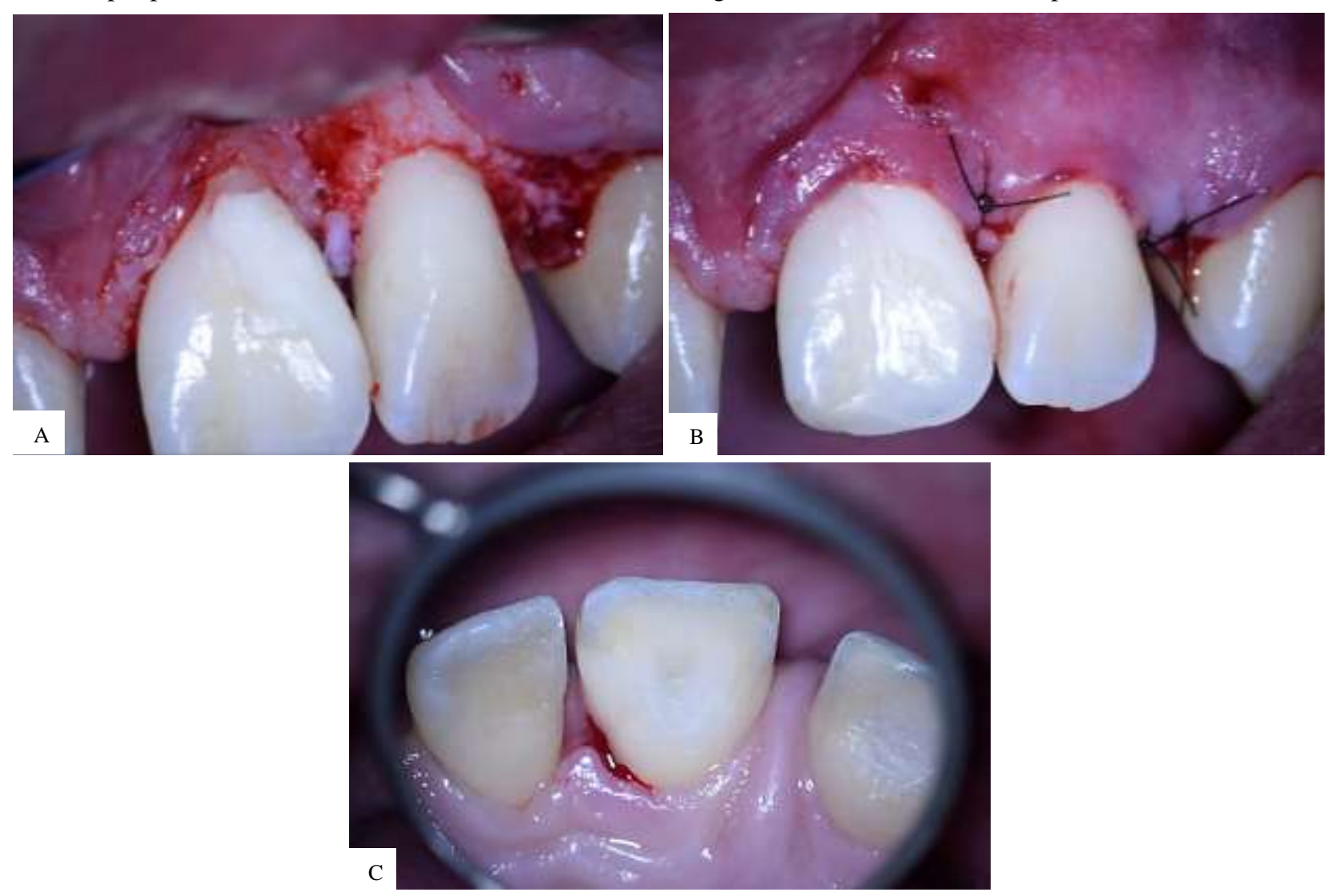

Source: Authors. 
Figure 5. A) Obturation of the root canal of tooth 11. B) Obturation of tooth 21 conditioned in the apical region of the root canal and fiberglass post in the middle and cervical thirds of the canal.
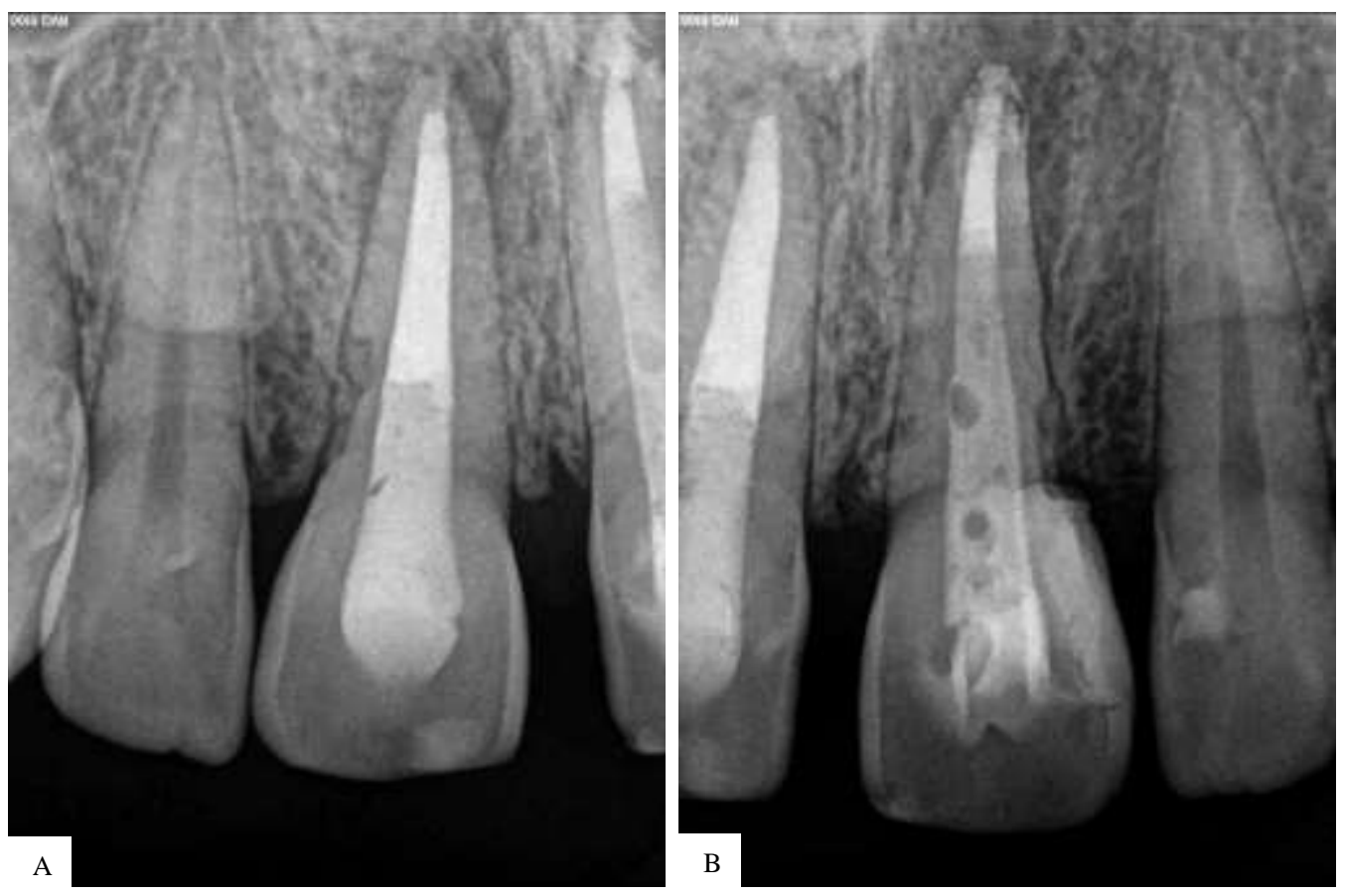

Source: Authors.

Figure 6. 7 months follow-up x-ray. Showing the recession of the periapical lesion on tooth 21 and stabilization of the resorption areas of teeth 11 and 21 .

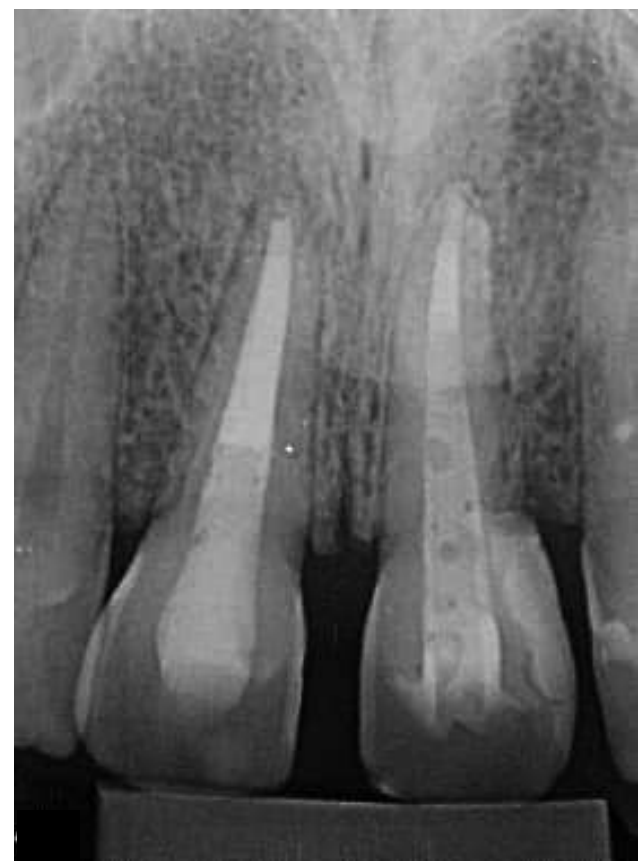

Source: Authors.

\section{Discussion}

The most frequent causes for the occurrence of trauma are sports activities, cycling, traffic accidents, falls, and violence (Kallel et al., 2020; Zaleckiene et al., 2014). Some anatomical features, such as pronounced overhang and inadequate lip coverage, may be predisposing factors for trauma (Zaleckiene et al., 2014; Lima et al., 2017). The age group with the highest 
prevalence of trauma is between seven and twelve years old and the male gender suffers much more dental trauma than the female gender (Dua \& Sharma, 2012). The records of the present case are consistent with those in the literature as it refers to a 10 years old male patient, with a traumatic injury suffered at 10 years old due to a fall from a bicycle.

Pulp necrosis and root resorption were complications that occurred in the long term of the progression of the case presented in this report. However, as there was no follow-up, it is not possible to precise the evolution of the pathology. According to the literature, when pulp necrosis occurs, after the occurrence of dislocation or avulsion, bacteria start to contaminate the root canal and its by-products and toxins can reach the outer surface of the root through the dentinal tubules, generating the external root resorption process (Finucane \& Kinirons, 2003). In addition, the physical action of trauma on the periodontium and cementum contributes to these complications (Mavridou et al., 2017).

In this case, in addition to external root resorption, there was also resorption of the dental crown. Clinically, the patient presented gingival tissue infiltration in the gap formed by the dentin tissue resorption and a slight pink coloration in the dental crown. The pink area is most often considered an inherent feature of internal coronary resorption. However, in some cases, it may be external resorption, which moved towards the tooth enamel, reaching the dentin, and exposing the underlying tissue (Consolaro, 2016).

The lack of periodic follow-up of the patient in this study contributed to the worsening of the situation, increasing the post-traumatic complications involved. The literature shows that complications resulting from trauma can occur weeks, months, or even years after the accident, for this reason, dental injuries require long-term care (Hecova et al., 2010; Yoshpe et al., 2020). The patient needs to be properly monitored, as permanent teeth with fully formed roots are at increased risk of developing pulp necrosis after trauma (Hammel \& Fischel, 2019; Kallel et al., 2020).

The prognosis of traumatic injuries depends on the quickness of the intervention on the damaged teeth, as delays in the treatment can influence the outcome of the case (Elbay et al., 2014). When endodontic treatment is procrastinated, pulp infection added to periodontium damage can result in the progression of the external root resorption (Lima et al., 2017). As the patient only received adequate treatment six years after the occurrence of the extrusive dislocation, in addition to pulp necrosis and sinus tract, the teeth also presented resorption, with both radicular and coronary foci. Most likely, these resorption pictures occurred due to the rupture of the vascular-nervous bundle and contamination of the root canal causing pulp necrosis. Besides, the delay in searching for endodontic treatment could have worsened the prognosis. Nevertheless, the elimination of the canal contamination and proper endodontic treatment with the use of a high-concentrated chemical irrigant, and a calcium hydroxide medication, lead to the closure of the sinus tract, remission of the apical lesion, and stabilized the environment resulting in the successful treatment of the root resorption.

\section{Conclusion}

Trauma episodes, of any intensity, cannot be neglected. It is necessary to monitor the vitality of the pulp, as well as monitor periodontal health, to prevent or act immediately on possible post-traumatic complications that may arise. The patient and their guardians need to be well educated about the importance of periodic visits to the dentist, as the earlier the treatment, the better the prognosis of the condition. The endodontic treatment with intracanal medication and the sealing of the resorption area were successful to preserve the traumatized tooth.

We suggest that future clinical research must be developed to establish adequate protocols for the management of root and crown resorption trough randomized clinical trials with long term follow-up. In addition, the case reports expose the treatment approach adopted for a given situation, significantly contributing to daily clinical practice. 


\section{References}

Abbott P. V. (2016). Prevention and management of external inflammatory resorption following trauma to teeth. Australian dental journal, 61 Suppl 1, 82-94. https://doi.org/10.1111/adj.12400

Ahmed, N., Gopalakrishnan, Mony, B., \& Parthasarthy, H. (2014). External cervical resorption case report and a brief review of literature. Journal of natural science, biology, and medicine, 5(1), 210-214. https://doi.org/10.4103/0976-9668.127336

Aidos, H., Diogo, P., \& Santos, J. M. (2018). Root Resorption Classifications: A Narrative Review and a Clinical Aid Proposal for Routine Assessment. European endodontic journal, 3(3), 134-145. https://doi.org/10.14744/eej.2018.33043

Bratteberg, M., Thelen, D. S., Klock, K. S., \& Bårdsen, A. (2021). Traumatic dental injuries and pulp sequelae in an adolescent population. Dental traumatology: official publication of International Association for Dental Traumatology, 37(2), 294-301. https://doi.org/10.1111/edt.12635

Consolaro A. (2016). External cervical resorption: diagnostic and treatment tips. Dental press journal of orthodontics, 21(5), 19-25. https://doi.org/10.1590/2177-6709.21.5.019-025.oin

de Souza, B., Dutra, K. L., Reyes-Carmona, J., Bortoluzzi, E. A., Kuntze, M. M., Teixeira, C. S., Porporatti, A. L., \& De Luca Canto, G. (2020). Incidence of root resorption after concussion, subluxation, lateral luxation, intrusion, and extrusion: a systematic review. Clinical oral investigations, 24(3), 1101-1111. https://doi.org/10.1007/s00784-020-03199-3

Dua, R., \& Sharma, S. (2012). Prevalence, causes, and correlates of traumatic dental injuries among seven-to-twelve-year-old school children in Dera Bassi. Contemporary clinical dentistry, 3(1), 38-41. https://doi.org/10.4103/0976-237X.94544

Elbay, Ü. Ş., Baysal, A., Elbay, M., \& Sarıdağ, S. (2014). Multidisciplinary approach to delayed treatment of traumatic teeth injuries involving extrusive luxation, avulsion and crown fracture. Operative dentistry, 39(6), 566-571. https://doi.org/10.2341/13-116-S

Finucane, D., \& Kinirons, M. J. (2003). External inflammatory and replacement resorption of luxated, and avulsed replanted permanent incisors: a review and case presentation. Dental traumatology: official publication of International Association for Dental Traumatology, 19(3), 170-174. https://doi.org/10.1034/j.1600-9657.2003.00154.x

Gijón, V. R., Martín, C. L., Encinas, R., \& Navajas, J. M. (2016). Aetiological, Histopathological, Clinical, Diagnostic and Therapeutical Features of Idiopathic Cervical Resorption. Dental update, 43(10), 964-970. https://doi.org/10.12968/denu.2016.43.10.964

Hammel, J. M., \& Fischel, J. (2019). Dental Emergencies. Emergency medicine clinics of North America, 37(1), 81-93. https://doi.org/10.1016/j.emc.2018.09.008

Hecova, H., Tzigkounakis, V., Merglova, V., \& Netolicky, J. (2010). A retrospective study of 889 injured permanent teeth. Dental traumatology: official publication of International Association for Dental Traumatology, 26(6), 466-475. https://doi.org/10.1111/j.1600-9657.2010.00924.x

Kallel, I., Douki, N., Amaidi, S., \& Ben Amor, F. (2020). The Incidence of Complications of Dental Trauma and Associated Factors: A Retrospective Study. International journal of dentistry, 2020, 2968174. https://doi.org/10.1155/2020/2968174

Lima, T., Silva, E., Gomes, B., Almeida, J., Zaia, A. A., \& Soares, A. J. (2017). Relationship between Initial Attendance after Dental Trauma and Development of External Inflammatory Root Resorption. Brazilian dental journal, 28(2), 201-205. https://doi.org/10.1590/0103-6440201701299

Mavridou, A. M., Bergmans, L., Barendregt, D., \& Lambrechts, P. (2017). Descriptive Analysis of Factors Associated with External Cervical Resorption. Journal of endodontics, 43(10), 1602-1610. https://doi.org/10.1016/j.joen.2017.05.026

Mordini, L., Lee, P., Lazaro, R., Biagi, R., \& Giannetti, L. (2021). Sport and Dental Traumatology: Surgical Solutions and Prevention. Dentistry journal, 9(3), 33. https://doi.org/10.3390/dj9030033

Munoz-Sanchez, M. L., Decerle, N., Devoize, L., Nicolas, E., Cousson, P. Y., \& Veyrune, J. L. (2021). Dental Trauma Management in a Young Teenager through Endodontics and Implantology: A Case Report. Healthcare (Basel, Switzerland), 9(5), 542. https://doi.org/10.3390/healthcare9050542

Oliveira, L. de C., Gonçalves, D. F. M.., Ramos, F. de S. e S., Mauro, G. V., Mauro, S. J., Mestrener, S. R., \& Fagundes, T. C. (2021). A multidisciplinary approach for external cervical resorption: A case report with 5-year follow-up. Research, Society and Development, 10(9), e35310918029. https://doi.org/10.33448/rsd-v10i9.18029

Patel, S., Lambrechts, P., Shemesh, H., \& Mavridou, A. (2018). European Society of Endodontology position statement: External Cervical Resorption. International endodontic journal, 51(12), 1323-1326. https://doi.org/10.1111/iej.13008

Pereira, S. A., Shitsuka, D. M., Parreira, F. J., Shitsuka, R. (2018). Metodologia da pesquisa científica. UFSM.

Ramachandran, A., Khan, S., Al-Maslamani, M., \& Baskaradoss, J. K. (2021). Pattern of Traumatic Dental Injuries Among Adults. Open access emergency medicine: OAEM, 13, 201-206. https://doi.org/10.2147/OAEM.S311113

Ribeiro, A. P. F., Tozzi, T. C. F., Tumelero, S., Carrijo, G. A. N., Vieria, L. R., Loureiro, C., \& Jacinto, R. de C. (2021). Knowledge and prevalence of trauma and evaluation of the impact of educational and preventive actions on a population of athletes. Research, Society and Development, 10(4), e16210413913. https://doi.org/10.33448/rsd-v10i4.13913

Zaleckiene, V., Peciuliene, V., Brukiene, V., \& Drukteinis, S. (2014). Traumatic dental injuries: etiology, prevalence and possible outcomes. Stomatologija, 16(1), 7-14. 